\title{
A Tale of Two Liberalisms? Attitudes toward Minority Religious Symbols in Quebec and Canada
}

\author{
Luc Turgeon $^{1 \star}$, Antoine Bilodeau ${ }^{2}$, Stephen E. White ${ }^{3}$ and Ailsa Henderson ${ }^{4}$ \\ ${ }^{1}$ School of Political Studies, University of Ottawa, FSS 7005, 120 University, Ottawa (Ontario), K1N 6N5, \\ ${ }^{2}$ Department of Political Science, Concordia University, Henry F. Hall, 1455 De Maisonneuve West, \\ Montreal (Quebec), H3 G 1M8, ${ }^{3}$ Department of Political Science, Carleton University, B640 Loeb Building, \\ 1125 Colonel By Drive, Ottawa (Ontario), K1S 5B6 and ${ }^{4}$ Department of Political Science, University of \\ Edinburgh, 3.09 Chrystal Macmillan Building, 15a George Square, Edinburgh (UK), EH 9LD \\ *Corresponding author. E-mail: lturgeon@uottawa.ca
}

\begin{abstract}
Proponents of restrictions on the wearing of religious symbols in public institutions in Quebec have often framed their support in the language of liberalism, with references to "gender equality", "state neutrality" and "freedom of conscience". However, efforts to account for support for restrictions on minority religious symbols rarely mention liberalism. In this article, we test the hypothesis that holding liberal values might have different attitudinal consequences in Quebec and the rest of Canada. Our findings demonstrate that holding liberal values is associated with support for restrictions on the wearing of minority religious symbols in Quebec, but it is associated with opposition to such restrictions in the rest of Canada. Moreover, this difference between Quebec and the rest of Canada in the relationship between liberal values and support for restrictions on minority religious symbols can explain Quebecers' greater support for restrictions.
\end{abstract}

\section{Résumé}

Les partisans de restrictions au port de symboles religieux dans les institutions publiques du Québec ont souvent formulé leur appui dans le langage du libéralisme, par des références à "l'égalité des sexes ", " la neutralité de l'État " et " la liberté de conscience ». Toutefois, les recherches visant à expliquer les motivations des partisans de ces restrictions examinent rarement le rôle du libéralisme. Dans cet article, nous vérifions

We would like to thank Benjamin Ferland for his very thoughtful comments and suggestions on an earlier draft of this article, as well as the journal's anonymous reviewers. We want to acknowledge the financial support of the Social Sciences and Humanities Research Council of Canada. The survey used in this study was made possible thanks to the financial support of the following organizations: the Secrétariat aux affaires intergouvernementales canadiennes of the Quebec government; the Institute for Research on Public Policy; the Canadian Network for Research on Terrorism, Security and Society; the Chaire de recherche du Canada en études québécoises et canadiennes de l'Université du Québec à Montréal; and Concordia University. The authors remain solely responsible for the interpretation of the data.

(C) Canadian Political Science Association (l'Association canadienne de science politique) and/et la Société québécoise de science politique 2019 
l'hypothèse selon laquelle l'adhésion aux valeurs libérales pourrait avoir des conséquences comportementales différentes au Québec et dans le reste du Canada. Nos résultats démontrent que le fait d'exprimer des valeurs libérales est associé à un plus fort appui aux restrictions au port de symboles religieux minoritaires au Québec, mais à une plus forte opposition à de telles restrictions dans le reste du Canada. De plus, cette différence entre le Québec et le reste du Canada dans la relation entre les valeurs libérales et l'appui aux restrictions sur les symboles religieux minoritaires peut expliquer pourquoi les Québécois appuient davantage de telles restrictions.

Keywords: public opinion; religious symbols; Quebec; Canada; liberalism

\section{Introduction}

In the fall of 2013, the Parti Québécois government introduced the Charter of Quebec Values. The Charter proposed to ban public employees from wearing "overt and conspicuous" (Gionnavetti, 2013) religious symbols. Although the legislative proposal would have banned all religious symbols-including Christian ones-the public debates focused primarily on minority religious symbols, such as the hijab, turban or kippa. While the Charter proposal sparked intense debates in Quebec, opposition to it was especially strong in the rest of Canada (Angus Reid Global, 2013), where it was denounced as illiberal.

To explain Quebecers' support for restrictions on minority religious symbols in the public sphere, commentators have stressed interpretations ranging from Quebec's status in Canada to its fraught history with the Catholic Church (Iacovino, 2015; Burchardt, 2016). Although many of the Charter's proponents framed their support in the language of liberalism, with references to "gender equality", "state neutrality" and "freedom of conscience", efforts to account for support for restrictions on minority religious symbols rarely mention liberalism. ${ }^{1}$ For some commentators, references to liberal values by supporters of personal restrictions on minority religious symbols constitute "faulty rationalization for Quebec's official bigotry" (Siddiqui, 2013; see also Bakali, 2015). Such doubts are not unwarranted; there is growing evidence that far-right parties in Europe have co-opted the language of gender equality and liberal values in order to legitimize antiimmigration and anti-minority positions (Betz and Meret, 2009; Mayer, 2013).

Liberals, however, have often disagreed about what ought to be the role of the liberal state. Key to such debate has been whether the state should promote, reflect or enforce liberal values, even through the use of "illiberal means" (Triadafilopoulos, 2011). A number of scholars have proposed different categories to make sense of those distinct interpretations: procedural and substantive liberalisms (Taylor, 1994), enlightenment and reformation liberalisms (Galston, 1995), or British and French liberalisms (Joppke, 2009). Implicit in these analyses is the idea that liberalism can have distinct policy implications, in large part because it is embedded in different contexts. Also implicit is the idea that, from the point of view of public opinion, public discourse around liberalism may vary and, in different settings, exert entirely different influences on public policy attitudes. 
In this regard, liberalism is arguably similar to other political ideologies, such as patriotism, nationalism or regionalism, in which the specific impact of the ideology has been shown to be context dependent (Billiet et al., 2003; Ceobanu and Escandell, 2008; Citrin et al., 2012). According to Citrin et al. (2012: 532), official policy and elite discourses around the nation vary, and since "mass opinion imbibes the wine poured by dominant elites", the impact of, for example, patriotism on mass publics differs across policy contexts.

In this article, we test the hypothesis that holding liberal values might have different attitudinal consequences in Quebec than it does in the rest of Canada, even if overall professed support for liberal values might not be dissimilar in those two societies. More precisely, our expectation is that holding liberal values is associated with support for restrictions on the wearing of minority religious symbols in public institutions in Quebec, but with opposition to such restrictions in the rest of Canada. We also explore whether this difference in the relationship between liberal values and support for restrictions on minority religious symbols in Quebec and the rest of Canada can explain Quebecers' greater support for restrictions. To test these hypotheses, we rely on a survey that we designed and that was administered in January and February 2014 to 6,400 Canadians, as the debate over the Charter of Quebec Values was unfolding.

\section{Liberalism and Support for Restrictions on Minority Religious Symbols}

An examination of the relationship between liberalism and attitudes toward minority religious symbols must begin with a discussion about what it means to hold liberal values. Liberals share a belief in the primacy of liberty as a political value. By liberal values, then, we refer to a set of attitudes stressing individual freedom. Over the years, several studies have identified attitudes that emphasize the importance of individual freedom as constituting a distinctive and reasonably consistent set of values (Schwartz, 1994; Inglehart and Welzel, 2005). ${ }^{2}$ However, as we outline in this section, there is significant disagreement among liberals when it comes to the role of the state in the promotion or enforcement of those values.

According to Sawitri Saharso (2013: 208), "Liberal principles are generic and hence there is a range within which they can be interpreted." For John Gray (2000: 2), liberalism has two faces: seen from one side, liberalism is "the pursuit of an ideal form of life"; seen from the other, it is "the search for terms of peace among different ways of life". Gray's conception bears a resemblance to William Galston's (1995) distinction between enlightenment and reformation liberalism: enlightenment liberalism, which entails a "commitment to sustained rational examination of self, others, and social practices", prioritises individual autonomy (521); reformation liberalism, which entails a commitment by liberal institutions to tolerance and diversity, privileges individual choices, whether they are perceived to be the product of rational examination or not. Other scholars distinguish between French and British (or "Anglo-Saxon") forms of liberalism (Bowen, 2006; Joppke, 2009). Echoing Isaiah Berlin's distinction between positive and negative liberty, John Bowen argues that the difference between the French and British approaches to secularism is essentially Rousseau against Locke: "freedom through the state against freedom from the state" (2006: 15). What these different 
dichotomies underline is that liberals can have different visions of the role of the state in the promotion of freedom. More specifically, liberals on either side of this fault line can disagree as to whether the state should actively reflect, promote and even enforce liberal values. Different understandings of the role of the state can therefore vary among individuals-in that the understandings reflect the particular interpretation of liberalism to which an individual adheres-but they can also be influenced by context. The role of the liberal state can be the object of intense debates among elites and can vary across time and space. In addition, one particular perspective can become dominant over time and can become accepted by the wider public.

\section{Liberalism in Quebec and the Rest of Canada}

In the study of liberalism in Quebec and Canada, the literature also points to the existence of distinctive views of the role of the state in enforcing liberal values. In his well-known essay The Politics of Recognition, Charles Taylor (1994) argues that two liberalisms cohabitate in Canada: one in Quebec and the other in the rest of Canada. Whereas "procedural liberalism" is said to predominate in English-speaking Canada, a form of "substantive liberalism" is perceived to predominate in Quebec. Procedural liberalism is associated with a neutral stance by the state on what constitutes the good life, as well as with the precedence of individual rights. Substantive liberalism is not neutral on what constitutes the good life and is willing to restrict some rights in order to promote collective goals. Taylor was writing, however, in the context of debates around Quebec's linguistic laws. While these different interpretations of liberalism would suggest greater openness in Quebec to state intervention to promote a given conception of the good life, it is only in recent years that liberal intellectuals and politicians in Quebec have proposed state regulation of individual expressions of religiosity. In addition, polling in the 1990s showed no significant attitudinal difference between Quebec and the rest of Canada on support for wearing religious symbols. ${ }^{3}$ Two liberalisms there might have been, but they had failed to generate different courses of action from successive Quebec governments or differences of opinion between Quebecers and other Canadians. What, then, can explain the contrasting trajectories of Quebec and the rest of Canada in the past three decades?

In Quebec, a number of scholars have argued that either in the wake of 9/11 or due to increasing concern over demands for religious accommodations by religious minorities, the "renewed model" of French laïcité that emerged in the early 2000s in the wake of the Stasi Commission ${ }^{4}$ has become an inspiration for many Quebec intellectuals and politicians, following the province's accommodation crisis (Weinstock, 2007; Koussens and Amiraux, 2014). Despite the idea of a French variant of liberalism, when it comes to the state regulation of religion, France's laicité had, until the early 1990s, more in common with Locke than with Rousseau (or Voltaire), as it focused more on the institutional separation between church and state than on individual displays of religiosity (Baubérot, 2009; Koussens and Amiraux, 2014). In the contemporary period, it was only in the 1990s, in the context of debates around the headscarf, that a number of intellectuals and politicians began promoting a vision of liberalism (and laicité) that called on the state to 
regulate individual expressions of beliefs and, in so doing, serve as an agent of religious emancipation (Koussens and Amiraux, 2014: 67). It is this version of French laïcité that influenced numerous Quebec intellectuals and politicians, as shown by Pauline Marois's declaration that France's model of laïcité was an inspiration for her Charter proposal (Journet, 2013). In Quebec, many intellectuals, politicians and social activists defended this model of laïcité explicitly on liberal grounds, arguing that it would preserve the neutrality of the state or that it would preserve respect for gender equality and the rights of LGBTQ+ communities (Weinstock, 2007).

In the rest of Canada, on the other hand, the 1990s saw important shifts in intellectual discourses around diversity, religious accommodations and the role of the state in a liberal society. According to Elke Winter (2011: 201-7), the second half of the 1990s saw a growing consensus among elites in Canada about the central value of multiculturalism, partly in reaction to Quebec nationalism. Consequently, the dominant contemporary form of liberalism in Canada as a whole is "liberal multiculturalism", which, in the words of Triadafilopoulos (2011: 863), "counsels negotiations, compromise and a willingness to accommodate groups whose religious beliefs and cultural practices may diverge from those of the majority." For Triadafilopoulos, this form of liberalism is very much in the "reformation" strand of liberalism. In Quebec, multiculturalism remains much more contested by intellectuals and politicians alike (Cardinal, 2017; Labelle, 2008).

A central argument of this article is that these contemporary changes in elite discourses in Canada and Quebec are reflected in the different relationships between liberalism and citizen attitudes toward minority religious symbols. As explained in greater detail in the methodology section, our questionnaire allows us to indirectly test the presence of two interpretations of liberalism by exploring attitudes toward distinct policy proposals regarding restrictions on the wearing of religious symbols.

\section{Prejudice, Cultural Threat and Religiosity: Alternative Perspectives}

In addition to the hypothesis that liberal values have different attitudinal consequences in Quebec and in the rest of Canada, we also test whether distinctive effects of liberal values account for the differences in attitudes toward religious symbols in these two societies. Liberalism is not usually invoked to account for differences between Quebecers and other Canadians on such matters as minority religious symbols in public institutions. Instead, prejudice and other forms of out-group antipathy are typically cited when discussing the support of Quebecers for such restrictions (Winter, 2014; Bakali, 2015). Indeed, research in Europe demonstrates that opposition to the place of minority religions in the public sphere is associated with generalized prejudice (Helbling, 2014; Van der Noll and Saroglou, 2015) or negative attitudes toward Muslims, in particular (Saroglou et al., 2009; Van der Noll and Saroglou, 2015). Research suggests Quebecers (or French Canadians) are more likely than other Canadians to hold negative attitudes toward ethnic and racial minorities (Berry and Kalin, 1995; Bilodeau et al., 2012); consequently, the source of Quebecers' greater opposition to minority religious symbols might well be the result of a greater degree of out-group antipathy.

Another potential source of difference is the cultural insecurity of Quebecers. The key role played by feelings, discourses and narratives of cultural threat in the 
political life of what Daiva Stasiulus (2013) has referred to as the "worrier nation" has often been raised, including in the report of the Bouchard-Taylor Commission. The question is whether cultural insecurity can explain Quebec's stronger opposition to minority religious symbols. Group threat theory suggests it might. The original formulation of group threat theory stressed that majority groups are likely to view minority groups as a threat to their socio-economic position (Blumer, 1958; Levine and Campbell, 1972). Another variant of the theory posits that threats can also be "symbolic" or "cultural" (Kinder and Sears, 1981; Velasco González et al., 2008). Such threats, the theory argues, are rooted in fears that out-groups (such as religious minorities) threaten the culture, values or status of the majority. In a cross-national study, Van der Noll (2010) observes that feelings of threat, including symbolic threat, are associated with support for a ban on the headscarves in public places; the same could hold true in Quebec.

Yet another potential explanation is different degrees of religiosity in Quebec and the rest of Canada. Religiosity refers to the active practice of rituals and to the importance of religion in one's life. According to Modood (1994: 72), the main divide over religious issues is now not between different religious groups but between "those who think religion has a place in a secular public culture and those who don't". A number of studies have shown that higher levels of religiosity are associated with greater support for the accommodation of religious minorities by public institutions or with more positive attitudes toward religious minorities (Clement, 2013; Van der Noll and Saroglou, 2015). As such, greater support for restrictions on the presence of religious symbols in public institutions in Quebec, including minority religious symbols, might be explained by the lower level of religiosity of Quebecers compared to other Canadians (Eagle, 2011; Meunier and Wilkins-Laflamme, 2011).

\section{Methodology and Data}

In order to test the hypotheses presented above, we rely on data from an online survey of 6,400 Canadians stratified by province that we conducted in January and February $2014 .{ }^{5}$ We rely on indicators measuring support for restrictions on minority religious symbols in three scenarios. First, respondents were asked whether it is acceptable or unacceptable for a police officer on duty to exhibit religious symbols such as a headscarf or a turban. The Bouchard-Taylor Commission in Quebec recommended that public servants who hold coercive powers, such as police officers, should not be allowed to exhibit any religious symbols. Respondents were also asked whether it is acceptable or unacceptable for teachers at a public school to exhibit minority religious symbols. While not a recommendation of the Bouchard-Taylor Commission, the Charter of Quebec Values proposed to extend restrictions on religious symbols to all employees of publicly financed institutions. The third indicator extends restrictions to students at a public school. Such a proposal was neither part of the recommendations of the Bouchard-Taylor commission nor of the Charter of Quebec Values. It has not been the subject of either public or intellectual debates in recent years. These different indicators therefore vary in the extent to which they were embedded within elite discourses. In Quebec, elite cues on the relationship between liberalism and attitudes toward minority religious symbols would have been 
more prevalent on the issue of restrictions for police officers and less prevalent on restrictions for students. We are interested to see not only whether liberalism pushes attitudes in different directions in Quebec and the rest of Canada but also whether the relationship between liberalism and support for restrictions on minority religious symbols depends on which groups those restrictions are imposed.

The data indicate that opinions about restrictions on minority religious symbols depend on the target of those restrictions and also that opinions about restrictions are systematically different in Quebec compared to the rest of Canada. Support for restrictions is strongest for police officers on duty, with 74 per cent of Quebecers and 45 per cent of other Canadians in favour of restricting minority religious symbols in this scenario. Support is somewhat lower for restrictions targeted at teachers at a public school, with 59 per cent of Quebecers and 29 per cent of other Canadians in favour. Support is lowest for restrictions targeted at students in public schools, with only 37 per cent of Quebecers and 20 per cent of other Canadians in favour.

These frequency distributions suggest the three survey items might represent different degrees of difficulty with regard to the underlying concept: support for restrictions on minority religious symbols. That is, respondents find it easier to support restrictions on police than on teachers, and easier to support restrictions on teachers than on students. One possible measurement strategy, then, is to use all three items to construct a single Guttman or Mokken scale measuring support for restrictions on minority religious symbols (Van Schuur, 2003). Although employing a single dependent variable measure would simplify the presentation of our empirical results, using such a scale would potentially miss important differences in the sources of support for restrictions on police, teachers and students. Therefore, we analyze each of the three items separately.

Why are Quebecers more supportive than other Canadians of restrictions on minority religious symbols? One possibility is that the levels of the values and attitudes associated with views on minority religious symbols are systematically different in these two contexts; that is, perhaps Quebecers are more supportive of restrictions because they are more liberal, more prejudiced, more culturally insecure, or less religious than other Canadians. To verify this possibility, we compare the values and attitudes of Quebecers and other Canadians in relation to liberal values, prejudice, cultural insecurity and religiosity. To measure liberal values, we use a four-item index, where 10 means strong liberal values and 0 means weak liberal values. ${ }^{6}$ Quebecers express somewhat stronger liberal values than other Canadians do (7.0 vs. 6.4). To measure prejudice, we measure feelings toward ethnic and religious minority groups, where 10 means very positive feelings (no prejudice) and 0 means very negative feelings (strong prejudice). Quebecers express somewhat less positive feelings toward minority groups than other Canadians (6.3 vs. 6.8). We also include two variables measuring whether respondents have distinctive feelings toward Muslims and Jews. The expectation is that the relationship between prejudice and support for restrictions on minority religious symbols might be stronger for these two minority religious groups. These two variables ( -10 to 10$)$ measure the gap between feelings toward Muslims or Jews and feelings toward other groups; they take a positive value when feelings toward Muslims or Jews are more positive than for other groups and take a negative value when feelings toward Muslims or 
Jews are more negative than for other groups. The value for Quebecers' feelings toward Muslims was 1.4 points lower than for other minority groups, compared to other Canadians' feelings toward Muslims, which was 1.1 points lower. In contrast, while Quebecers express marginally more negative feelings toward Jews than for other minority groups (-.50), other Canadians express marginally more positive feelings for this group (.30). Cultural insecurity was measured by asking respondents whether they view immigration as a threat to the culture of their province. Such a perception is more widespread in Quebec than elsewhere in Canada (38\% vs. $29 \%)^{7}$ Finally, to assess respondents' religiosity, we asked them to indicate whether they agreed or disagreed with the following statement: "Religion is very important in my life"; 13 per cent of Quebecers and 24 per cent of other Canadians express a strong agreement with the statement.

At first glance, the comparison of levels of attitudes and values between Quebecers and other Canadians provides little leverage for explaining differences in support for restrictions on minority religious symbols. Although Quebecers appear somewhat more prejudicial toward minority groups, as well as more culturally insecure and less religious, the magnitude of the observed differences is unlikely to explain the large gap in support for restrictions on minority religious symbols. It is nevertheless possible that, taken altogether, the combined differences in these values and attitudes may explain the gap between Quebecers and other Canadians.

However, another possibility is that the effects of one set of values, in particularliberal values-are systematically different in Quebec than in the rest of Canada. This is our central hypothesis. We expect that even though Quebecers and other Canadians exhibit broadly similar liberal values, those values tend to increase support for restrictions on minority religious symbols in Quebec but decrease support for restrictions in the rest of Canada. In the following section, we present the results of multivariate analyses designed to test both of these possibilities.

\section{Explaining the Quebec/Rest of Canada Gap}

We investigate support for each of the three scenarios for restrictions separately for two reasons. First, we expect that the effect of liberal values on support for restrictions in Quebec depends on the target of those restrictions. Second, given that support for restrictions varies widely across scenarios, many other correlates of support might also be different across the scenarios.

We have tested three binary logistic regression models for each scenario. The dependent variables indicate whether respondents find it unacceptable (1) or acceptable (0) for a person to display minority religious symbols. Model I includes only provincial dummies to verify whether other provinces stand out in terms of support for restriction on minority religious symbols; Ontario is the reference category. Model II verifies whether differences in levels of attitudes and values explain the gap between Quebecers and other Canadians. Our expectation is that controlling for these attitudes and values will not account for the gap. Model III turns to our main hypothesis, namely that liberal values are associated with attitudes toward restrictions on minority religious symbols both in Quebec and the rest of Canada. In Quebec, liberal values would be associated with greater support for restrictions on minority religious symbols. In the rest of Canada, liberal values would be 
associated with weaker support for such restrictions. It is this difference that would explain the Quebec/rest of Canada gap. In order to empirically test this possibility, Model III examines whether the relationship between liberal values and support for restrictions on minority religious symbols goes in opposite directions in Quebec, compared to the rest of Canada, and whether that difference effectively explains the Quebec/rest of Canada gap. To that end, we include an interaction variable for liberal values in Quebec.

The results for all three sets of models are reported in Table 1. Model I confirms that Quebecers are more supportive of restrictions on minority religious symbols than are other Canadians. ${ }^{8}$ It also indicates that New Brunswick is the only other province where support for restrictions is significantly stronger than in Ontario for all three proposed scenarios, with differences of 11 points for police officers, 13 points for teachers, and 8 points for students. ${ }^{9}$ Model II indicates that support for restrictions on minority religious symbols is indeed related to levels of religiosity and prejudice toward ethnic and religious minority groups; the more religious Canadians are, and the more positive their views of ethnic and religious minorities, the less inclined they are to support restrictions on minority religious symbols. Similarly, the analyses indicate that those who dislike Muslims more than other groups are even more supportive of restrictions on minority religious symbols. These relationships hold under all three scenarios for restrictions. Cultural insecurity is also a significant correlate of support for restrictions: those who see immigrants as a cultural threat are more supportive of restrictions for police officers, teachers and students. Finally, the analyses indicate that the stronger the liberal values of Canadians are, the less supportive they are of restrictions on minority religious symbols. The relationship, however, is statistically significant only under the scenarios involving police officers and students, and in both cases the relationship is modest in strength. Most importantly, despite being significantly related to restrictions on minority religious symbols, these values and attitudes-prejudice, religiosity, cultural insecurity and liberal values-do little to explain the gap between Quebecers and other Canadians. The coefficients measuring the greater support among Quebecers remain positive and significant in Model II.

Model III tests our main hypothesis concerning the different impact of liberal values in Quebec and in the rest of Canada. We have two sets of expectations. First, if liberal values have different attitudinal consequences in Quebec than in the rest of Canada, then when we introduce an interaction variable to assess the conditional effects of liberal values in Quebec, the coefficient should be significant and positive (that is, the effect should be in the direction opposite that of the rest of Canada). Second, if the different impact of liberalism explains the gap in support for restrictions on minority religious symbols between Quebec and the rest of Canada, then the coefficient for the "Quebec" dummy variable should be effectively reduced to zero when the interaction variable is included in the analysis.

The results in Model III are clearly consistent with the first set of expectations. Under all three scenarios, the coefficient for liberal values, which now represents the estimated conditional effect of liberal values for Canadians outside of Quebec, is negative and statistically significant ( -.09 for police officers, -.09 for teachers and -.10 for students). ${ }^{10}$ Moreover, the interaction term for the estimated effect of liberal values in Quebec is statistically significant and positive. ${ }^{11}$ The differences between Quebec and the rest of Canada are illustrated in Figure 1, which 
Table 1. Explaining Quebecers' Greater Support for Restrictions on Minority Religious Symbols

\begin{tabular}{|c|c|c|c|c|c|c|c|c|c|}
\hline & \multicolumn{3}{|c|}{$\begin{array}{l}\text { Police Officer on Duty } \\
\qquad(N=4,971)\end{array}$} & \multicolumn{3}{|c|}{$\begin{array}{l}\text { Teacher in Public } \\
\text { School }(N=4,968)\end{array}$} & \multicolumn{3}{|c|}{$\begin{array}{l}\text { Student in Public } \\
\text { School }(N=4,972)\end{array}$} \\
\hline & I & II & III & I & II & III & 1 & II & III \\
\hline \multicolumn{10}{|l|}{ Province (ref. = Ontario) } \\
\hline Newfoundland \& Labrador & $\begin{array}{l}-.07 \\
(.18)\end{array}$ & $\begin{array}{l}.25 \\
(.20)\end{array}$ & $\begin{array}{l}.26 \\
(.20)\end{array}$ & $\begin{array}{c}-.34 \\
(.21)\end{array}$ & $\begin{array}{l}-.06 \\
(.22)\end{array}$ & $\begin{array}{l}-.06 \\
(.23)\end{array}$ & $\begin{array}{l}-.12 \\
(.22)\end{array}$ & $\begin{array}{l}.22 \\
(.25)\end{array}$ & $\begin{array}{l}.22 \\
(.25)\end{array}$ \\
\hline Prince Edward Island & $\begin{array}{l}-.24 \\
(.23)\end{array}$ & $\begin{array}{l}-.09 \\
(.25)\end{array}$ & $\begin{array}{l}-.10 \\
(.26)\end{array}$ & $\begin{array}{l}-.14 \\
(.26)\end{array}$ & $\begin{array}{c}.05 \\
(.27)\end{array}$ & $\begin{array}{c}.04 \\
(.28)\end{array}$ & $\begin{array}{l}-.06 \\
(.27)\end{array}$ & $\begin{array}{l}.08 \\
(.32)\end{array}$ & $\begin{array}{c}.07 \\
(.32)\end{array}$ \\
\hline Nova Scotia & $\begin{array}{c}-.12 \\
(.14)\end{array}$ & $\begin{array}{c}.06 \\
(.17)\end{array}$ & $\begin{array}{c}.07 \\
(.17)\end{array}$ & $\begin{array}{r}-.09 \\
(.15)\end{array}$ & $\begin{array}{c}.06 \\
(.18)\end{array}$ & $\begin{array}{c}.08 \\
(.18)\end{array}$ & $\begin{array}{l}-.09 \\
(.17)\end{array}$ & $\begin{array}{c}.10 \\
(.19)\end{array}$ & $\begin{array}{r}.11 \\
(.19)\end{array}$ \\
\hline New Brunswick & $\begin{array}{l}.46^{\mathrm{b}} \\
(.15)\end{array}$ & $\begin{array}{l}.64^{\mathrm{a}} \\
(.16)\end{array}$ & $\begin{array}{l}.64^{\mathrm{a}} \\
(.17)\end{array}$ & $\begin{array}{l}.58^{\mathrm{a}} \\
(.15)\end{array}$ & $\begin{array}{l}.77^{\mathrm{a}} \\
(.17)\end{array}$ & $\begin{array}{l}.78^{\mathrm{a}} \\
(.17)\end{array}$ & $\begin{array}{l}.43^{\mathrm{b}} \\
(.16)\end{array}$ & $\begin{array}{l}.60^{\mathrm{C}} \\
(.18)\end{array}$ & $\begin{array}{l}.61^{b} \\
(.18)\end{array}$ \\
\hline Manitoba & $\begin{array}{r}-.09 \\
(.14)\end{array}$ & $\begin{array}{c}.02 \\
(.15)\end{array}$ & $\begin{array}{c}.02 \\
(.16)\end{array}$ & $\begin{array}{l}-.35^{\mathrm{c}} \\
(.15)\end{array}$ & $\begin{array}{c}-.31 \\
(.17)\end{array}$ & $\begin{array}{c}-.32 \\
(.18)\end{array}$ & $\begin{array}{l}-.45^{\mathrm{b}} \\
(.17)\end{array}$ & $\begin{array}{r}-.43^{\mathrm{c}} \\
(.19)\end{array}$ & $\begin{array}{r}-.43^{\mathrm{C}} \\
(.19)\end{array}$ \\
\hline Saskatchewan & $\begin{array}{l}.32^{c} \\
(.15)\end{array}$ & $\begin{array}{c}.25 \\
(.16)\end{array}$ & $\begin{array}{c}.23 \\
(.16)\end{array}$ & $\begin{array}{c}.15 \\
(.15)\end{array}$ & $\begin{array}{r}.06 \\
(.17)\end{array}$ & $\begin{array}{c}.02 \\
(.17)\end{array}$ & $\begin{array}{l}-.02 \\
(.17)\end{array}$ & $\begin{array}{r}-.20 \\
(.19)\end{array}$ & $\begin{array}{r}-.22 \\
(.19)\end{array}$ \\
\hline Alberta & $\begin{array}{c}.21 \\
(.11)\end{array}$ & $\begin{array}{c}.22 \\
(.13)\end{array}$ & $\begin{array}{c}.22 \\
(.13)\end{array}$ & $\begin{array}{r}-.06 \\
(.12)\end{array}$ & $\begin{array}{c}-.11 \\
(.14)\end{array}$ & $\begin{array}{c}-.13 \\
(.14)\end{array}$ & $\begin{array}{l}-.21 \\
(.14)\end{array}$ & $\begin{array}{c}-.30 \\
(.16)\end{array}$ & $\begin{array}{r}-.32^{\mathrm{C}} \\
(.16)\end{array}$ \\
\hline British Columbia & $\begin{array}{c}-.21 \\
(.12)\end{array}$ & $\begin{array}{r}-.22 \\
(.13\end{array}$ & $\begin{array}{c}-.23 \\
(.13)\end{array}$ & $\begin{array}{c}-.20 \\
(.13)\end{array}$ & $\begin{array}{c}-.20 \\
(.14)\end{array}$ & $\begin{array}{c}-.21 \\
(.15)\end{array}$ & $\begin{array}{l}-.33^{c} \\
(.14)\end{array}$ & $\begin{array}{r}-.35^{c} \\
(.16)\end{array}$ & $\begin{array}{r}-.35^{\mathrm{C}} \\
(.16)\end{array}$ \\
\hline Quebec & $\begin{array}{l}1.18^{b} \\
(.12)\end{array}$ & $\begin{array}{l}1.23^{a} \\
(.14)\end{array}$ & $\begin{array}{c}-.30 \\
(.38)\end{array}$ & $\begin{array}{l}1.15^{\mathrm{a}} \\
(.12)\end{array}$ & $\begin{array}{l}1.15^{\mathrm{a}} \\
(.14)\end{array}$ & $\begin{array}{l}-.46 \\
(.35)\end{array}$ & $\begin{array}{l}.66^{\mathrm{a}} \\
(.13)\end{array}$ & $\begin{array}{c}.57^{\mathrm{a}} \\
(.14)\end{array}$ & $\begin{array}{c}-.16 \\
(.36)\end{array}$ \\
\hline Religiosity & & $\begin{array}{r}-.35^{\mathrm{c}} \\
(.14)\end{array}$ & $\begin{array}{c}-.33^{\mathrm{C}} \\
(.15)\end{array}$ & & $\begin{array}{c}-.58^{\mathrm{a}} \\
(.15)\end{array}$ & $\begin{array}{c}-.57^{\mathrm{a}} \\
(.15)\end{array}$ & & $\begin{array}{r}-.26 \\
(.16)\end{array}$ & $\begin{array}{r}-.26 \\
(.16)\end{array}$ \\
\hline Feelings/ minority groups & & $\begin{array}{c}-.20^{\mathrm{a}} \\
(.02)\end{array}$ & $\begin{array}{c}-.21^{\mathrm{a}} \\
(.02)\end{array}$ & & $\begin{array}{c}-.22^{\mathrm{a}} \\
(.02)\end{array}$ & $\begin{array}{c}-.23^{\mathrm{a}} \\
(.02)\end{array}$ & & $\begin{array}{c}-.26^{\mathrm{a}} \\
(.03)\end{array}$ & $\begin{array}{r}-.26^{\mathrm{a}} \\
(.03)\end{array}$ \\
\hline Feelings/Jews & & $\begin{array}{c}.03 \\
(.04)\end{array}$ & $\begin{array}{c}.03 \\
(.04)\end{array}$ & & $\begin{array}{c}-.01 \\
(.04)\end{array}$ & $\begin{array}{c}-.01 \\
(.04)\end{array}$ & & $\begin{array}{c}.02 \\
(.03)\end{array}$ & $\begin{array}{c}.02 \\
(.03)\end{array}$ \\
\hline Feelings/ Muslims & & $\begin{array}{c}-.27^{\mathrm{a}} \\
(.03)\end{array}$ & $\begin{array}{c}-.27^{\mathrm{a}} \\
(.03)\end{array}$ & & $\begin{array}{c}-.29^{\mathrm{a}} \\
(.03)\end{array}$ & $\begin{array}{c}-.29^{\mathrm{a}} \\
(.03)\end{array}$ & & $\begin{array}{r}-.24^{\mathrm{a}} \\
(.03)\end{array}$ & $\begin{array}{c}-.24^{\mathrm{a}} \\
(.03)\end{array}$ \\
\hline Immigration threat & & $\begin{array}{l}1.01^{\mathrm{a}} \\
(.11)\end{array}$ & $\begin{array}{l}1.02^{\mathrm{a}} \\
(.11)\end{array}$ & & $\begin{array}{c}.69^{\mathrm{a}} \\
(.11)\end{array}$ & $\begin{array}{l}.70^{\mathrm{a}} \\
(.11)\end{array}$ & & $\begin{array}{l}.71^{\mathrm{a}} \\
(.12)\end{array}$ & $\begin{array}{c}.72^{\mathrm{a}} \\
(.12)\end{array}$ \\
\hline Liberal Values & & $\begin{array}{c}-.05^{c} \\
(.02)\end{array}$ & $\begin{array}{c}-.09^{a} \\
(.02)\end{array}$ & & $\begin{array}{c}-.04 \\
(.02)\end{array}$ & $\begin{array}{c}-.09^{b} \\
(.03)\end{array}$ & & $\begin{array}{c}-.08^{c} \\
(.03)\end{array}$ & $\begin{array}{r}-.10^{\mathrm{b}} \\
(.03)\end{array}$ \\
\hline Liberal Values $x$ Quebec & & & $\begin{array}{l}.22^{\mathrm{a}} \\
(.05)\end{array}$ & & & $\begin{array}{c}.23^{\mathrm{a}} \\
(.05)\end{array}$ & & & $\begin{array}{l}.11^{\mathrm{c}} \\
(.05)\end{array}$ \\
\hline Constant & $\begin{array}{c}-.20^{c} \\
(.08)\end{array}$ & $\begin{array}{l}1.06^{\mathrm{a}} \\
(.27)\end{array}$ & $\begin{array}{l}1.32^{\mathrm{a}} \\
(.28)\end{array}$ & $\begin{array}{c}-.79^{\mathrm{a}} \\
(.09)\end{array}$ & $\begin{array}{c}.59^{c} \\
(.28)\end{array}$ & $\begin{array}{c}.93^{\mathrm{b}} \\
(.29)\end{array}$ & $\begin{array}{r}-1.21 \\
(.10)\end{array}$ & $\begin{array}{c}.44 \\
(.30)\end{array}$ & $\begin{array}{c}.60 \\
(.32)\end{array}$ \\
\hline Pseudo $\mathrm{R}^{2}$ & .044 & .189 & .195 & .050 & .189 & .196 & .022 & .168 & .169 \\
\hline
\end{tabular}

Note: Entries are binary logit coefficients with robust standard errors in parentheses. Source: Provincial Diversity Project

${ }^{\mathrm{a}} p<.001 ;{ }^{\mathrm{b}} p<.01 ;{ }^{\mathrm{c}} p<.05$

reports predicted probabilities for the net effect of liberal values in Quebec and in the rest of Canada under each of the three scenarios. To calculate these probabilities, we translated the log-odds derived from the binomial logit results into predicted probabilities in which we vary the value of liberal values (for Quebec and for the rest of Canada) while keeping all other independent variables constant at their means. The results show the divergent effects of liberal values in Quebec and the rest of Canada under both the police officers and teachers scenarios: in Quebec, the stronger the respondents' liberal values, the more likely they are to support restrictions for police officers and teachers. Our estimates suggest that 

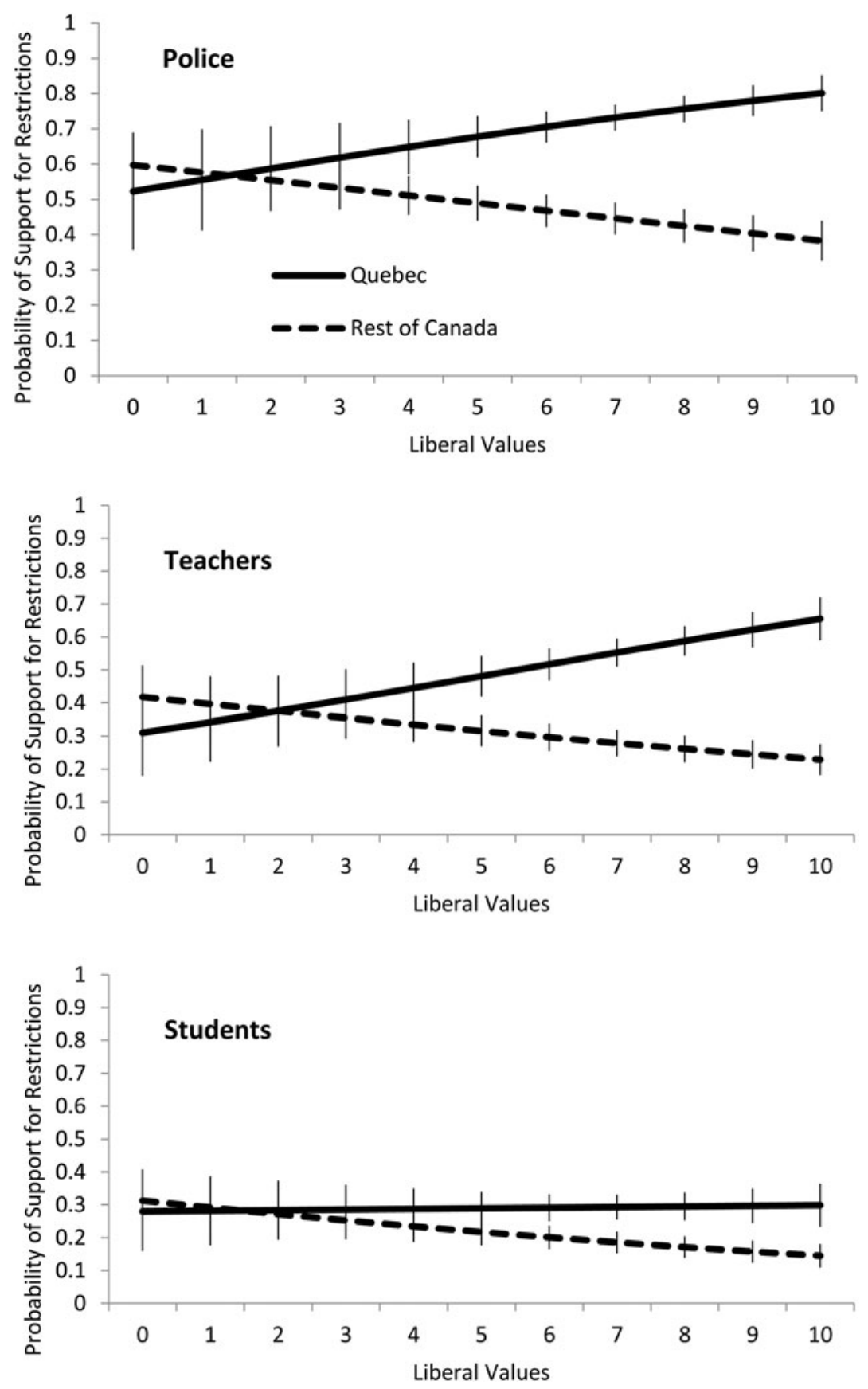

Figure 1. Support for Restrictions on Minority Religious Symbols by Liberal Values: Quebec and the Rest of Canada (Predicted Probabilities). 
Quebecers who have liberal values one standard deviation above the sample mean for liberal values are 13 per cent and 18 per cent more likely than those with liberal values one standard deviation below the mean to support restrictions for police officers and teachers, respectively ( $p<.05$ for both differences). In the rest of Canada, the stronger the respondents' liberal values, the less likely they are to support such restrictions: those who have liberal values one standard deviation above the sample mean for liberal values are estimated to be 11 per cent and 9 per cent less likely than those with liberal values one standard deviation below the mean to support restrictions for police officers and teachers, respectively $(p<.05$ for both differences). The situation is different, however, when it comes to restrictions on students at public schools. Under that scenario, whereas the net effect of liberal values on support for restrictions is negative in the rest of Canada, there is no discernible effect in Quebec.

Our results, which show divergent effects of liberal values on support for restrictions on minority religious symbols, explain the differences in aggregate opinions between Quebec and the rest of Canada. Were it not for the effects of liberal values, Quebecers would be no more supportive of restrictions than are other Canadians. This is best illustrated in Figure 1: when liberal values are absent (that is, when the value for that variable is set to zero), Quebecers are, if anything, slightly less supportive of restrictions on minority religious symbols than are other Canadians (though the difference is not statistically significant). Hence, the analyses suggest that if liberalism had no effect in both societies, Quebecers and other Canadians would support restrictions on minority religious symbols in roughly equal numbers. ${ }^{12}$

\section{Language and Support for Restrictions on Minority Religious Symbols}

The above findings suggest a cultural cleavage between Quebec and the rest of Canada. What role, if any, does language play in these findings? Is it possible that the cultural cleavage over liberalism masks a linguistic divide between Francophones and other Canadians across the country? Table 1 indicated that New Brunswick is the only other province where support for restrictions on minority religious symbols is stronger than in the reference category (in this case, Ontario), suggesting language may well be a salient consideration; New Brunswick is, after all, the province with the largest proportion of Francophones after Quebec. To verify the linguistic hypothesis, we performed additional analyses in which we distinguish Francophones from non-Francophones in Quebec, New Brunswick and the rest of Canada. ${ }^{13}$

The results presented in Table 2 (Model I) indicate a Francophone effect in Quebec, where Francophones are more likely than residents of Ontario (our reference category) to support restrictions on minority religious symbols under all three scenarios. ${ }^{14}$ In contrast, non-Francophones in Quebec are just as opposed as Ontarians to restrictions on police officers, and even more opposed than Ontarians to restrictions on teachers and students. The Francophone effect is also observed in New Brunswick, where Francophones express greater support for restrictions under all three scenarios. ${ }^{15}$ However, outside of Quebec and New Brunswick, there are no significant linguistic differences.

We performed a final set of analyses, in which we examined the effect of liberal values for Francophones and non-Francophones in Quebec and New Brunswick. 
Table 2. Language and Support for Restrictions on Minority Religious Symbols

\begin{tabular}{|c|c|c|c|c|c|c|}
\hline & \multicolumn{2}{|c|}{$\begin{array}{l}\text { Police Officer on } \\
\text { Duty }(N=4,961)\end{array}$} & \multicolumn{2}{|c|}{$\begin{array}{l}\text { Teacher in Public } \\
\text { School }(N=4,958)\end{array}$} & \multicolumn{2}{|c|}{$\begin{array}{l}\text { Student in } \\
\text { Public School } \\
(N=4,962)\end{array}$} \\
\hline & I & II & 1 & II & 1 & II \\
\hline \multicolumn{7}{|l|}{ Province (ref. = Ontario) } \\
\hline Newfoundland \& Labrador & $\begin{array}{c}.25 \\
(.20)\end{array}$ & $\begin{array}{c}.26 \\
(.20)\end{array}$ & $\begin{array}{r}-.06 \\
(.22)\end{array}$ & $\begin{array}{r}-.06 \\
(.23)\end{array}$ & $\begin{array}{c}.21 \\
(.25)\end{array}$ & $\begin{array}{c}.22 \\
(.25)\end{array}$ \\
\hline Prince Edward Island & $\begin{array}{l}-.11 \\
(.25)\end{array}$ & $\begin{array}{l}-.12 \\
(.25)\end{array}$ & $\begin{array}{c}.03 \\
(.27)\end{array}$ & $\begin{array}{r}.02 \\
(.28)\end{array}$ & $\begin{array}{l}.06 \\
(.31)\end{array}$ & $\begin{array}{c}.05 \\
(.31)\end{array}$ \\
\hline Nova Scotia & $\begin{array}{c}.05 \\
(.17)\end{array}$ & $\begin{array}{r}.06 \\
(.17)\end{array}$ & $\begin{array}{c}.06 \\
(.18)\end{array}$ & $\begin{array}{r}.07 \\
(.18)\end{array}$ & $\begin{array}{l}.09 \\
(.19)\end{array}$ & $\begin{array}{l}.10 \\
(.19)\end{array}$ \\
\hline Manitoba & $\begin{array}{c}.01 \\
(.15)\end{array}$ & $\begin{array}{c}.01 \\
(.16)\end{array}$ & $\begin{array}{r}-.33 \\
(.17)\end{array}$ & $\begin{array}{l}-.33 \\
(.17)\end{array}$ & $\begin{array}{r}-.44^{\mathrm{c}} \\
(.19)\end{array}$ & $\begin{array}{r}-.44^{\mathrm{c}} \\
(.19)\end{array}$ \\
\hline Saskatchewan & $\begin{array}{c}.26 \\
(.16)\end{array}$ & $\begin{array}{c}.25 \\
(.16)\end{array}$ & $\begin{array}{c}.06 \\
(.17)\end{array}$ & $\begin{array}{r}.04 \\
(.17)\end{array}$ & $\begin{array}{r}-.19 \\
(.19)\end{array}$ & $\begin{array}{r}-.20 \\
(.19)\end{array}$ \\
\hline Alberta & $\begin{array}{c}.21 \\
(.13)\end{array}$ & $\begin{array}{c}.21 \\
(.13)\end{array}$ & $\begin{array}{c}-.13 \\
(.14)\end{array}$ & $\begin{array}{l}-.15 \\
(.14)\end{array}$ & $\begin{array}{l}-.33^{\mathrm{c}} \\
(.16)\end{array}$ & $\begin{array}{r}-.33^{\mathrm{C}} \\
(.16)\end{array}$ \\
\hline British Columbia & $\begin{array}{l}-.22 \\
(.13)\end{array}$ & $\begin{array}{l}-.23 \\
(.13)\end{array}$ & $\begin{array}{c}-.21 \\
(.14)\end{array}$ & $\begin{array}{l}-.21 \\
(.15)\end{array}$ & $\begin{array}{r}-.35^{\mathrm{c}} \\
(.16)\end{array}$ & $\begin{array}{r}-.36^{\mathrm{C}} \\
(.16)\end{array}$ \\
\hline Religiosity & $\begin{array}{l}-.31^{\mathrm{c}} \\
(.15)\end{array}$ & $\begin{array}{l}-.31^{\mathrm{c}} \\
(.15)\end{array}$ & $\begin{array}{r}-.56^{\mathrm{a}} \\
(.15)\end{array}$ & $\begin{array}{l}-.56^{\mathrm{a}} \\
(.15)\end{array}$ & $\begin{array}{l}-.24 \\
(.16)\end{array}$ & $\begin{array}{c}-.24 \\
(.16)\end{array}$ \\
\hline Feelings/minority groups & $\begin{array}{l}-.20^{\mathrm{a}} \\
(.02)\end{array}$ & $\begin{array}{l}-.21^{\mathrm{a}} \\
(.02)\end{array}$ & $\begin{array}{l}-.22^{\mathrm{a}} \\
(.03)\end{array}$ & $\begin{array}{l}-.23^{\mathrm{a}} \\
(.03)\end{array}$ & $\begin{array}{l}-.26^{\mathrm{a}} \\
(.03)\end{array}$ & $\begin{array}{c}-.26^{\mathrm{a}} \\
(.03)\end{array}$ \\
\hline Feelings/Jews & $\begin{array}{c}.05 \\
(.04)\end{array}$ & $\begin{array}{c}.05 \\
(.04)\end{array}$ & $\begin{array}{c}.02 \\
(.04)\end{array}$ & $\begin{array}{r}.02 \\
(.04)\end{array}$ & $\begin{array}{c}.04 \\
(.03)\end{array}$ & $\begin{array}{c}.04 \\
(.03)\end{array}$ \\
\hline Feelings/Muslims & $\begin{array}{c}-.26^{\mathrm{a}} \\
(.03)\end{array}$ & $\begin{array}{c}-.26^{\mathrm{a}} \\
(.03)\end{array}$ & $\begin{array}{c}-.28^{\mathrm{a}} \\
(.03)\end{array}$ & $\begin{array}{l}-.27^{\mathrm{a}} \\
(.03)\end{array}$ & $\begin{array}{l}-.23^{\mathrm{a}} \\
(.03)\end{array}$ & $\begin{array}{c}-.23^{\mathrm{a}} \\
(.03)\end{array}$ \\
\hline Immigration is cultural threat & $\begin{array}{c}.98^{\mathrm{a}} \\
(.11)\end{array}$ & $\begin{array}{l}1.00^{\mathrm{a}} \\
(.11)\end{array}$ & $\begin{array}{l}.65^{\mathrm{a}} \\
(.11)\end{array}$ & $\begin{array}{c}.66^{\mathrm{a}} \\
(.11)\end{array}$ & $\begin{array}{l}.68^{\mathrm{a}} \\
(.12)\end{array}$ & $\begin{array}{l}.69^{\mathrm{a}} \\
(.12)\end{array}$ \\
\hline Francophones & $\begin{array}{c}.26 \\
(.26)\end{array}$ & $\begin{array}{c}.27 \\
(.26)\end{array}$ & $\begin{array}{c}.33 \\
(.27)\end{array}$ & $\begin{array}{r}.33 \\
(.27)\end{array}$ & $\begin{array}{r}.25 \\
(.29)\end{array}$ & $\begin{array}{r}.25 \\
(.29)\end{array}$ \\
\hline Francophones/Quebec & $\begin{array}{l}1.47^{\mathrm{a}} \\
(.28)\end{array}$ & $\begin{array}{c}-.34 \\
(.51)\end{array}$ & $\begin{array}{l}1.34^{\mathrm{a}} \\
(.28)\end{array}$ & $\begin{array}{l}-.18 \\
(.48)\end{array}$ & $\begin{array}{l}.61^{\mathrm{c}} \\
(.30)\end{array}$ & $\begin{array}{c}-.01 \\
(.47)\end{array}$ \\
\hline Non-Francophones/Quebec & $\begin{array}{c}-.03 \\
(.22)\end{array}$ & $\begin{array}{c}-.54 \\
(.64)\end{array}$ & $\begin{array}{c}-.78^{\mathrm{b}} \\
(.28)\end{array}$ & $\begin{array}{c}-1.49^{\mathrm{c}} \\
(.71)\end{array}$ & $\begin{array}{l}-.85^{\mathrm{c}} \\
(.34)\end{array}$ & $\begin{array}{c}-.65 \\
(.68)\end{array}$ \\
\hline Francophones/NB & $\begin{array}{c}.93^{b} \\
(.32)\end{array}$ & $\begin{array}{c}.59 \\
(.70)\end{array}$ & $\begin{array}{l}1.10^{b} \\
(.33)\end{array}$ & $\begin{array}{r}.79 \\
(.70)\end{array}$ & $\begin{array}{l}.75^{\mathrm{C}} \\
(.35)\end{array}$ & $\begin{array}{c}.13 \\
(.64)\end{array}$ \\
\hline Non-Francophones/NB & $\begin{array}{l}.39^{c} \\
(.20)\end{array}$ & $\begin{array}{c}.58 \\
(.45)\end{array}$ & $\begin{array}{c}.47^{\mathrm{c}} \\
(.20)\end{array}$ & $\begin{array}{l}1.04^{c} \\
(.45)\end{array}$ & $\begin{array}{c}.41 \\
(.21)\end{array}$ & $\begin{array}{l}1.22^{b} \\
(.45)\end{array}$ \\
\hline Liberal Values & $\begin{array}{l}-.06^{b} \\
(.02)\end{array}$ & $\begin{array}{c}-.09^{a} \\
(.02)\end{array}$ & $\begin{array}{c}-.06^{c} \\
(.02)\end{array}$ & $\begin{array}{l}-.09^{b} \\
(.03)\end{array}$ & $\begin{array}{c}-.08^{b} \\
(.03)\end{array}$ & $\begin{array}{c}-.10^{\mathrm{b}} \\
(.03)\end{array}$ \\
\hline Lib. values Franco. in $Q C$ & & $\begin{array}{l}.25^{\mathrm{a}} \\
(.06)\end{array}$ & & $\begin{array}{l}.21^{\mathrm{a}} \\
(.05)\end{array}$ & & $\begin{array}{c}.09 \\
(.05)\end{array}$ \\
\hline Lib. values non-Franco. in $Q C$ & & $\begin{array}{c}.08 \\
(.09)\end{array}$ & & $\begin{array}{r}.11 \\
(.09)\end{array}$ & & $\begin{array}{c}-.04 \\
(.10)\end{array}$ \\
\hline Lib. values Franco. in NB & & $\begin{array}{c}.05 \\
(.09)\end{array}$ & & $\begin{array}{r}.05 \\
(.09)\end{array}$ & & $\begin{array}{c}.10 \\
(.08)\end{array}$ \\
\hline Lib. values non-Franco. in NB & & $\begin{array}{l}-.03 \\
(.07)\end{array}$ & & $\begin{array}{l}-.09 \\
(.07)\end{array}$ & & $\begin{array}{c}-.14 \\
(.07)\end{array}$ \\
\hline Constant & $\begin{array}{l}1.11^{\mathrm{a}} \\
(.27)\end{array}$ & $\begin{array}{l}1.31^{\mathrm{a}} \\
(.28)\end{array}$ & $\begin{array}{l}.68^{c} \\
(.28)\end{array}$ & $\begin{array}{l}.90^{\mathrm{a}} \\
(.30)\end{array}$ & $\begin{array}{c}.49 \\
(.31)\end{array}$ & $\begin{array}{c}.58 \\
(.32)\end{array}$ \\
\hline Pseudo $\mathrm{R}^{2}$ & .206 & .211 & .218 & .222 & .181 & .182 \\
\hline
\end{tabular}

Note: Entries are binary logit coefficients with robust standard errors in parentheses. Source: Provincial Diversity Project

${ }^{\text {a }} p<.001 ;{ }^{\text {b }} p<.01 ;{ }^{c} p<.05$ 
Model II in Table 2 reports these findings; in it, we focus our attention on whether the interaction effect for liberal values is positive and significant for Francophones in Quebec and New Brunswick and whether it helps to explain the gap between Francophones and non-Francophones in those two provinces. Among Francophones in Quebec, there is a positive and significant relationship between liberal values and support for restrictions on minority religious symbols for police officers and teachers. Moreover, the coefficients measuring the difference between Francophones in Quebec are substantially reduced and are no longer significant when the interaction variable is included. In none of the three scenarios is the interaction variable for liberal values significant for non-Francophones in Quebec. In the case of New Brunswick, we find little evidence that liberal values have an effect, either for Francophones or non-Francophones. Moreover, even though the coefficients measuring the difference between Francophones in New Brunswick and our reference category are no longer statistically significant once we include the interaction variable for liberal values, the coefficients barely shrink in size. Those findings confirm that there is something unique about the Quebec context when it comes to the relationship between liberal values and attitudes toward the presence of religious symbols in public institutions among Francophones.

\section{Conclusion}

The cleavage between Quebecers and other Canadians on restrictions on minority religious symbols is well documented. The roots of this cleavage, however, are more nebulous. In many European countries, where similar debates have polarized public opinion, out-group antipathy and low levels of religiosity have been found to influence attitudes toward the place of minority religions in public institutions (Helbling, 2014; Van der Noll and Saroglou, 2015). At first sight, these two explanations appear to apply well to Quebecers. Religiosity declined drastically after the Quiet Revolution and, as mentioned previously, a number of studies have observed a particular discomfort with ethnocultural diversity in Quebec. Our study acknowledges these assumptions and explores an alternative explanation, namely that the relationship between core liberal values and attitudes toward restrictions on minority religious symbols varies across Quebec and the rest of Canada. One explanation for this is the contemporary predominance of distinctive interpretations of liberalism in Quebec and the rest of Canada.

A number of scholars have argued that efforts to restrict the wearing of religious symbols in public institutions are to some degree motivated by a particular variant of liberalism. However, the few studies to empirically investigate whether liberal values have influenced public opinion on this matter have been inconclusive (Helbling, 2014; Saroglou et al., 2009). Gustavsson et al. (2016) argue that those inconclusive results stem, in part, from a reliance on measures of liberal values that fail to distinguish between different interpretations of liberalism. Employing two unique sets of indicators to measure enlightenment and reformation liberalism in the Netherlands, they observe that the former is associated with support for restrictions on religious symbols, while the latter is associated with opposition.

Like Gustavsson et al., we stress the significance of different interpretations of liberalism and their effects on attitudes toward minority religious symbols in 
different contexts. However, our study explored whether in two different settings, a single, common measure of liberalism relates in diametrically opposite manners to support for restrictions on minority religious symbols. Our expectation was that the gap in support for minority religious symbols between the two societies would be accounted for not by different levels of values or attitudes, such as prejudice, religiosity or even liberalism, but instead by a fundamentally different relationship between liberal values and support for restrictions on minority religious symbols in each society.

Our investigation lends support to these hypotheses. A single and common indicator of liberal values is related in diametrically opposite ways to support for restrictions on minority religious symbols in Quebec and the rest of Canada. Whereas in Quebec, holding stronger liberal values is associated with greater support for restrictions on minority religious symbols, in the rest of Canada, stronger liberal values are associated with weaker support for such restrictions. We interpret these empirical findings as consistent with the view that two different interpretations of liberalism predominate in Quebec and the rest of Canada and that these different interpretations of liberalism appear to explain the cleavage between Quebec and the rest of Canada when it comes to the place of minority religious symbols in the public sphere. That these findings vary according to whom is targeted by those restrictions also provides preliminary evidence that elite discourse might be driving this attitudinal fault line. A ban on minority religious symbols for students was less embedded within elite discourse in Quebec than an equivalent ban for police officers and teachers. The absence of a relationship in Quebec between liberal values and a ban on minority religious symbols for students offers important, albeit indirect, preliminary evidence that elite discourse plays a key role in Quebec. By way of contrast, in the rest of Canada, liberal values are consistently associated with opposition to restrictions on minority religious symbols, regardless of the target of those restrictions.

Let us be clear: xenophobia, feelings of cultural threat and religiosity undoubtedly structure public opinion on the presence of minority religious symbols in public institutions, both in Quebec and in the rest of Canada. However, these factors cannot account for the significant discrepancy between the policy preferences of mass publics of those two societies. The difference between Quebec and the rest of Canada appears instead to be a fundamental cultural difference-a tale of two liberalisms.

\section{Notes}

1 For an overview of discourses around the Charter, see Lamy (2015). A growing body of literature has explored the attitudes of Quebecers toward religious minority symbols (O'Neill et al., 2015; Ferland, 2018) or the Charter of Quebec Values (Tessier and Montigny, 2016; Bilodeau et al., 2018; Ferland, 2018). Other studies have also explored attitudes toward religious accommodation (Wright et al., 2017; Dufresne et al., 2018). However, none have systematically explored the impact of holding liberal values, although O'Neill et al. (2015) show the determinant role played by feminist arguments. Moreover, in a study of the sources of support for the Charter of Quebec Values (Bilodeau et al., 2018), we found that supporters of both the Charter and the removal of the crucifix from the National Assembly of Quebec were more liberal than those who opposed the Charter. In this article, we explore whether holding liberal values has distinct attitudinal consequences inside and outside Quebec. 
2 As Carmines and D'Amico (2015) note in their recent review of the literature, although earlier scholarship questioned whether ideological thinking structures mass public opinion, much contemporary work on ideology and public opinion has shifted away from a "traditional conception of ideology" - with an emphasis on opinion constraint and coherence-to a focus on the roles of core values and principles in structuring attitudes and action. Our focus on liberal values is consistent with this latter conception of ideology.

3 A Gallup Poll conducted in April 1990 found that 75 per cent of Canadians opposed allowing Royal Canadian Mounted Police officers to wear religious headwear. Opposition was the highest not in Quebec but in the Prairie provinces. See Canadian Institute of Public Opinion (1990).

4 The Stasi Commission was appointed to explore the application of the principle of laïcité in the French Republic. One of its main recommendations was to restrict the wearing of religious symbols in schools, which led to the adoption of the Loi sur les signes religieux dans les écoles publiques françaises. More broadly, the commission report stated that "the rise of new religious practices requires a renewed application of the laïcité principle." (Commission de réflexion sur l'application du principe de laïcité dans la République, 2003: 50; our translation).

5 The survey provides samples of 1,000 respondents for each of Quebec, Ontario, Alberta and British Columbia and samples of 500 respondents for other provinces, except for Prince Edward Island and Newfoundland and Labrador, for which the combined sample is 400 respondents. The fieldwork was conducted by Léger Marketing. All the data from the survey, the Provincial Diversity Project, will be publicly available in the summer of 2019 through the Canadian Opinion Research Archive.

6 See the appendix for more information on the construction of variables.

7 We also asked respondents whether immigration was a threat to the Canadian culture. We use the indicator about threat to the province instead of threat to Canada because it is more salient for Quebecers and because both indicators are equally salient for other Canadians; 29 per cent of Quebecers and 28 per cent of other Canadians say that immigration threatens Canadian culture.

8 Additional analyses were also performed in which we included a variable indicating whether respondents were Parti Québécois (PQ) supporters. This allowed us to verify whether including this variable in Model I explains the gap in support between Quebec and the rest of Canada for restrictions on minority religious symbols. The results indicate that although PQ supporters are indeed more likely to support restrictions on minority religious symbols, including such a variable does not explain the greater support for restrictions on minority religious symbols observed among Quebecers, and it does not explain the unique and positive relationship between liberal values and support for restrictions on minority religious symbols observed for Quebec (results not presented).

9 Reported differences are based on predicted probabilities derived from Model I.

10 A related question is whether those with liberal values in the Quebec context also want to restrict the display of Christian/majority symbols. Quebec respondents were asked whether they strongly agree, agree, disagree or strongly disagree that the crucifix should be removed from the National Assembly. In order to verify this possibility, we examined the relationship between liberal values and support for removing the crucifix at the National Assembly. These additional analyses indicate that those with stronger liberal values in Quebec express greater support for removing the crucifix from the National Assembly (results not presented). Such findings are thus consistent with our argument that, in Quebec, demands for restrictions on minority religious symbols are not motivated simply by prejudice or xenophobia. Unfortunately, no equivalent analyses can be performed for the rest of Canada because our data do not include any question on Christian/majority symbols for respondents outside of Quebec.

11 The interaction variable between Quebec and liberal values is statistically significant and positive even when other control variables are not included in the model (results not presented). Moreover, we also verified whether the positive relationship between liberal attitudes and support for restrictions on minority religious symbols was limited to Parti Québécois (PQ) supporters only (and therefore might not extend to the entire Quebec population). To do so, we included in the model another interaction variable between PQ supporters and liberal values. These additional analyses indicate that the interaction variable $P Q$ supporter/liberal values is not significant for any of the three different situations of restriction and that including this variable in the model does not impact on the other interaction variable Quebec/liberal attitudes. Results not presented.

12 Analyses were conducted including age, gender, education and belonging to a non-Christian religion. Including these variables does not alter the findings reported in Table 1. We did not include these variables in Table 1 because Quebec and the rest of Canada present a profile broadly comparable on these characteristics. Results not presented. 
13 We do not investigate Francophones in specific provinces other than Quebec and New Brunswick because their sample is too small. We use language spoken at home, as it is more representative of the language used by respondents than mother tongue.

14 In the case of students at a public school, the p-value for difference for Francophones in Quebec is equal to .056. 15 Non-Francophones in New Brunswick also appear more supportive of restrictions in all three scenarios, but for the students scenario, the difference is only statistically significant at the .10-level.

\section{References}

Angus Reid Global. 2013. "Quebecers, Canadians Split on Proposed Charter of Values." http://angusreid. org/quebecers-canadians-split-on-proposed-charter-of-values/ (December 16, 2018)

Bakali, Naved. 2015. "Contextualising the Quebec Charter of Values: How the Muslim 'Other' Is Conceptualised in Quebec." Culture and Religion 16 (4): 412-29.

Baubérot, Jean. 2009. "L'évolution de la laïcité en France : entre deux religions civiles." Diversité urbaine 9 (1): 9-25.

Berry, J. W. and Rudolf Kalin. 1995. "Multicultural and Ethnic Attitudes in Canada: An Overview of the 1991 Survey." Canadian Journal of Behavioural Science 27 (3): 301-20.

Betz, Hantz-Georg and Susi Meret. 2009. "Revisiting Lepanto: The Political Mobilization Against Islam in Contemporary Western Europe." Patterns of Prejudice 43 (3/4): 313-34.

Bilodeau, Antoine, Luc Turgeon and Ekrem Karakoç. 2012. "Small Worlds of Diversity: Views toward Immigration and Racial Minorities in Canadian Provinces." Canadian Journal of Political Science 45 (3): 579-605.

Bilodeau, Antoine, Luc Turgeon, Stephen White and Ailsa Henderson. 2018. "Strange Bedfellows? Attitudes toward Majority and Minority Religious Symbols in the Public Sphere." Politics and Religion 11 (2): 309-33.

Billiet, Jaak, Bart Maddens and Roeland Berteen. 2003. "National Identity and Attitude toward Foreigners in a Multinational State: A Replication." Political Psychology 24 (2): 241-57.

Blumer, Herbert. 1958. "Race Prejudice as a Sense of Group Position." Pacific Sociological Review 1 (1): 3-7.

Bowen, John R. 2006. Why the French Don't Like the Headscarves: Islam, the State, and the Public Space. Princeton: Princeton University Press.

Burchardt, Marian. 2016. "Recalling Modernity: How Nationalist Memories Shape Religious Diversity in Quebec and Catalonia." Nations and Nationalism 23 (3): 599-619.

Canadian Institute of Public Opinion (CIPO). 1990. Gallup Poll, April 1990, \#004_1 [Canada]. [public-use microdata file]. Toronto: Gallup Canada.

Cardinal, François. 2017 “Sale multiculturaliste!” La Presse, February 19. http://www.lapresse.ca/debats/editoriaux/francois-cardinal/201702/18/01-5071010-sale-multiculturaliste-.php (May 16, 2018).

Carmines, Edward G. and Nicholas J. D'Amico. 2015. "The New Look in Political Ideology Research." Annual Review of Political Science 18: 205-16.

Ceobanu, Alin M. and Xavier Escandell. 2008. "East Is West? National Feelings and Anti-Immigrant Sentiment in Europe." Social Science Research 37 (4): 1147-70.

Citrin, Jack, Richard Johnston and Matthew Wright. 2012. "Do Patriotism and Multiculturalism Collide? Competing Perspectives from Canada and the United States." Canadian Journal of Political Science 45 (3): $531-52$.

Clements, Ben. 2013. "Explaining Public Attitudes towards the Integration of Muslims in British Society: The 'Solidarity of the Religious'?" Journal of Contemporary Religion 28 (1): 49-65.

Commission de réflexion sur l'application du principe de lacité dans la République. 2003. Rapport au Président de la République. http://www.ladocumentationfrancaise.fr/var/storage/rapports-publics/ 034000725.pdf (May 16, 2018).

Dufresne, Yannick, Anja Kilibarda, André Blais and Alexis Bibeau. 2018. "Religiosity or Racism? The Bases of Opposition to Religious Accommodation in Quebec." Nations and Nationalism. https://doi.org/10. 1111/nana.12429.

Eagle, David E. 2011. "Changing Patterns of Attendance at Religious Services in Canada, 1986-2008." Journal for the Scientific Study of Religion 50 (1): 187-200.

Ferland, Benjamin. 2018. "L'impact des minorités visibles sur l'appui à la Charte des valeurs et l'interdiction des symboles religieux." Revue canadienne de science politique 51 (1): 23-59. 
Galston, William. 1995. “Two Concepts of Liberalism.” Ethics 105 (3): 516-34.

Gionnavetti, Justin. 2013. "Five Key Consequences of Quebec's Planned Charter of Values." The Globe and Mail, September 13. https://www.theglobeandmail.com/news/politics/five-key-consequences-ofquebecs-planned-charter-of-values/article14239113/ (December 16, 2018).

Gray, John. 2000. Two Faces of Liberalism. London: Polity.

Gustavsson, Gina, Jolanda van der Noll and Ralph Sundberg. 2016. "Opposing the Veil in the Name of Liberalism: Popular Attitudes to Liberalism and Muslim Veiling in the Netherlands." Ethnic and Racial Studies 39 (10): 1719-37.

Helbling, Marc. 2014. "Opposing Muslims and the Muslim Headscarf in Western Europe." European Sociological Review 30 (2): 242-57.

Iacovino, Raffaele. 2015. "Contextualizing the Charter of Values: Belonging without Citizenship in Quebec." Canadian Ethnic Studies 47 (1): 41-60.

Inglehart, Ronald and Christian Welzel. 2005. Modernization, Cultural Change, and Democracy: The Human Development Sequence. Cambridge: Cambridge University Press.

Joppke, Christian. 2009. Veil: Mirror of Identity. Cambridge: Polity Press.

Journet, Paul. 2013. "La laïcité française, une "inspiration” pour Marois." La Presse, December 13. http:// www.lapresse.ca/actualites/politique/politique-quebecoise/201312/13/01-4720644-la-laicite-francaise-uneinspiration-pour-marois.php (May 16, 2018).

Kinder, Donald D. and David O. Sears. 1981. "Prejudice and Politics: Symbolic Racism versus Racial Threats to the Good Life." Journal of Personality and Social Psychology 40 (3): 44-31.

Koussens, David and Valérie Amiraux. 2014. "Du mauvais usage de la laïcité française dans le débat public québécois." In Penser la laïcité québécoise: fondements et défense d'une laïcité ouverte au Québec, ed. Sébastien Lévesque. Québec: Presses de l'Université Laval.

Labelle, Micheline. 2008. "Les intellectuels québécois face au multiculturalisme : hétérogénéité des approches et des projets politiques." Canadian Ethnic Studies 40 (1): 33-56.

Lamy, Guillaume. 2015. Laïcité et valeurs québécoises. Les sources d'une controverse. Montreal: Québec-Amérique.

Levine, Robert A. and Donald T. Campbell. 1972. Ethnocentrism: Theories of Conflict, Ethnic Attitudes, and Group Behaviour. Oxford: John Wiley \& Sons.

Mayer, Nonna. 2013. "From Jean-Marie to Marine Le Pen: Electoral Change on the Far Right." Parliamentary Affairs 66 (1): 160-78.

Meunier, E.-Martin and Sarah Wilkins-Laflamme. 2011. "Sécularisation, catholicisme et transformation du régime de religiosité au Québec. Étude comparative avec le catholicisme au Canada (1968-2007)." Recherches sociographiques 52 (3): 683-729.

Modood, Tariq. 1994. "Establishment, Multiculturalism and British Citizenship." Political Quarterly 65 (1): 53-73.

O'Neill, Brenda, Elisabeth Gidengill, Catherine Côté and Lisa Young. 2015. "Freedom of Religion, Women's Agency and Banning the Face Veil: The Role of Feminist Beliefs in Shaping Women's Opinion." Ethnic and Racial Studies 38 (11): 1886-1901.

Saharso, Sawitri. 2013. "Conclusion: The Veil as a Case of Value Diversity and European Values." In Politics, Religion and Gender: Framing and Regulating the Veil, ed. Sieglinde Rosenberger and Birgit Sauer. London: Routledge.

Saroglou, Vassilis, Bahija Lamkaddem, Matthieu Van Pachterbeke and Coralie Buxant. 2009. "Host Society's Dislike of the Islamic Veil: The Role of Subtle Prejudice, Values, and Religion." International Journal of Intercultural Relations 33 (5): 419-28.

Schwartz, Shalom H. 1994. "Are There Universal Aspects in the Structure and Content of Human Values?" Journal of Social Issues $\mathbf{5 0}$ (4): 19-45.

Siddiqui, Haroon. 2013. "Faulty Rationalizations for Quebec's Official Bigotry." The Star (Toronto), September 18. https://www.thestar.com/opinion/columnists/2013/09/18/faulty_rationalizations_for_ quebecs_official_bigotry_siddiqui.html (December 16, 2018).

Stasiulus, Daiva. 2013. "Worrier Nation: Quebec's Value of Codes for Immigrants." Politikon 40 (1): 183-209.

Taylor, Charles. 1994. "The Politics of Recognition." In Multiculturalism : Examining the Politics of Recognition, ed. Amy Gutmann. Princeton: Princeton University Press.

Tessier, Charles and Éric Montigny. 2016. "Untangling Myths and Facts: Who Supported the Quebec Charter of Values?” French Politics 14 (2): 272-85. 
Triadafilopoulos, Triadafilos. 2011. "Illiberal Means to Liberal Ends? Understanding Recent Immigrant Integrations Policies in Europe." Journal of Ethnic and Migration Studies 37 (6): 861-80.

Van der Noll, Jolanda. 2010. "Public Support for a Ban on Headscarves: A Cross-National Perspective." International Journal of Conflict and Violence 4 (2): 191-204.

Van der Noll, Jolanda and Vassilis Saroglou. 2015. "Anti-Islam or Anti-Religion? Understanding Objection against Islamic Education." Journal of Ethnic and Migration Studies 41: 219-38.

Van Schuur, Wijbrandt H. 2003. "Mokken Scale Analysis: Between the Guttman Scale and Parametric Item Response Theory." Political Analysis 11 (2): 139-63.

Velasco González, Karina, Maykel Verkuyten, Jeroen Weesie and Edwin Poppe. 2008. "Prejudice towards Muslims in the Netherlands: Testing Integrated Threat Theory." British Journal of Social Psychology 47 (4): $667-85$.

Weinstock, Daniel. 2007. "La crise des accommodements au Québec: hypothèses explicatives." Éthique publique 9 (1): 20-26.

Winter, Elke. 2011. Us, Them, and Others: Pluralism and National Identity in Diverse Societies. Toronto: University of Toronto Press.

Winter, Stephen. 2014. "Cultural Politics Pathology: The Charter of Québec Values." Politics, Groups, and Identities 2 (4): 681-88.

Wright, Matthew, Richard Johnston, Jack Citrin and Stuart Soroka. 2017. "Multiculturalism and Muslim Accommodation: Policy and Predisposition across Three Political Contexts." Comparative Political Studies 50 (1): 102-32.

\section{Appendix Construction of Variables}

Religion is important in my life $1=$ strongly agree; .67 =agree; $.33=$ disagree; $0=$ strongly disagree Immigration is a threat to culture $1=$ Immigration is a threat to provincial culture.

of province

Feelings toward minority groups

Distinctive feelings toward Muslims

Distinctive feelings toward Jews

Liberal values

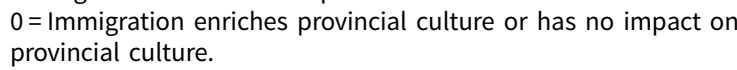
provincial culture.

0-10 seven-item scale, where 10 means very positive feelings for the following ethnic and religious minority groups: Blacks, Latinos, Chinese, Indians, Filipinos, Jews and Muslims.

Cronbach alpha $=.93$

-10 to 10 scale, where a positive score means more positive feelings toward Muslims than all minority groups and where a negative score means greater antipathy toward Muslims than all minority groups.

-10 to 10 scale, where a positive score means more positive feelings toward Jews than all minority groups and where a negative score means greater antipathy toward Jews than all minority groups.

0 to 10 scale made up of five indicators, where 10 means very liberal values and 0 means very weak liberal values:

Do you strongly, agree, disagree or strongly disagree with the following statements:

1. Society would be better off if more women stayed home with their children. (reverse coding)

2. It is too easy to get an abortion nowadays. (reverse coding)

3. Gays and lesbians should NOT be allowed to marry in Canada. (reverse coding)

4. Euthanasia (or assisted suicide) is never ethically justified. (reverse coding)

5. Canada should decriminalize prostitution.

(Cronbach alpha $=.68$ )

Cite this article: Turgeon L, Bilodeau A, White SE, Henderson A (2019). A Tale of Two Liberalisms? Attitudes toward Minority Religious Symbols in Quebec and Canada. Canadian Journal of Political Science 52, 247-265. https://doi.org/10.1017/S0008423918000999 